\title{
Study on MGNREGA Scheme: The Securing Employment Incomes, Utilization, Problems and Suggestions
}

\author{
Deepak Hembram $^{1 *}$, A.K. Bandyopadhyay ${ }^{1}$, Lokesh Kumar Tinde ${ }^{1}$, \\ Dibyendu Pal $^{1}$ and Kshitij Parmar ${ }^{2}$ \\ ${ }^{1}$ Department of Agricultural Extension, Bidhan Chandra Krishi Viswavidyalaya Mohanpur \\ District-Nadia West Bengal, 741252 India \\ ${ }^{2}$ Department of Agricultural Extension, Sardar Vallabhbhai Patel University of Agriculture and \\ Technology, Meerut, Uttar Pradesh, 250110, India \\ *Corresponding author
}

\section{Keywords \\ MGNREGA, Employment, Incomes, Utilization, India. \\ Article Info \\ Accepted: \\ 17 October 2017 \\ Available Online: \\ 10 December 2017}

\section{A B S T R A C T}

The act has helped the rural poor to secure their livelihood by providing employment and enhanced their social status through income generation. It has also improved the rural infrastructure by creation of assets which lead to sustainable development. The Mahatma Gandhi National Rural Employment Guarantee Act (MGNREGA) in an Indian law that aims to guarantee the 'Right to work' and ensure livelihood security in rural areas by providing at least 100 days of guarantee wage in a financial year to every household whose adult members volunteer to do unskilled manual work. This act has been designed to provide an ecological perspective in order to achieve longterm livelihood sustainability and this study was conducted under Nayagarm block in Paschim Medinipur District of West Bengal. Four villages were randomly selected from one block and from each village, 25 respondents randomly selected, making a sample of 100 respondents. The primary data were collected with the help of the personal interview method during the study period. After collection of data, data were processed and analyzed in accordance with the outline laid down for the purpose at the time of developing the research plan. Process implies editing, coding, classification and tabulation of collected data. The Main statistical tools and techniques used in the present study are as follows: score, mean score value, standard deviation, correlation coefficient and paired ' $t$ ' test. The finding of the study revealed that the difference between the mean annual incomes of the two gram panchayat is highly significant. Therefore the null hypothesis is rejected (i.e. the mean annual income of the beneficiary household did not differ significantly after obtaining wage employment under the MGREGA). 53 percent of the household beneficiaries utilized their increased income to make new houses, payment of wages is the major problems faced by the beneficiary households and 64 percent of the beneficiary household suggested for timely payment of wages. So to overcome such problems it can be suggested that, dedicated and fully trained full time professional should be appointed for the effective implementation of the scheme and efforts should be made to reduce the time gap between work done and payment received by rural laborers in NREGA or a program for generating public awareness about the program with the help of information technology should be initiated at a large scale at different time intervals. 


\section{Introduction}

The MNREGA being a flagship program of the government of India to provide employment for at least one hundred days to alleviate poverty due to acute unemployment in the rural areas has also been successfully implemented throughout West Bengal. The situation of unemployment was further compounded by the absence of any social mechanism.

There was therefore an urgent need to ensure a minimum number of days of employment in the shape of manual labour to the every household in the rural areas. The act has helped the rural poor to secure their livelihood by providing employment and enhanced their social status through income generation. It has also improved the rural infrastructure by creation of assets which lead to sustainable development. The Mahatma Gandhi National Rural Employment Guarantee Act (MGNREGA) in an Indian law that aims to guarantee the 'Right to work' and ensure livelihood security in rural areas by providing at least 100 days of guarantee wage in a financial year to every household whose adult members volunteer to do unskilled manual work.

This act has been designed to provide an ecological perspective in order to achieve long-term livelihood sustainability. Its primary objective is to augment wage employment and strengthen natural resources management (Poonia, 2012). The enactment of MGNREGA best reflects the Government of India's new resolve to strengthen the rural economy and livelihoods of the poor (Muthusamy, 2012). MGNREGA becomes an interesting subject to study because it is not only giving employment to the rural poor but also creating sustainable and durable assets in the village. The Act gives power to the daily wage labours to fight for their right to receive the wages that they must receive and not just a means of providing social security to its people but also an opportunity to promote over all community development and alter the balance of power in rural society (Bebrata, 2013). This act stipulates that wages will be equal for men and women and also committed to ensuring that at least 33 percent of the workers shall be women (Adhikari and Bhatia, 2010). The economic dependence of women on men in rural India plays a major role in the subjugation of women, and in this respect the MNREGA is an important tool of social change (Drèze and Christian, 2007). The present study was designed to know study on MGNREGA scheme: the securing employment incomes, utilization, problems and suggestions, with the following specific objectives.

Analyze the impact of the MNREGA on the socio-economic status of the beneficiaries.

To study the problems faced by the beneficiaries while attaining benefits from the program.

To study the suggestion of the beneficiary household to overcome the problems in gaining the benefits of the programme.

\section{Materials and Methods}

The study was conducted under Nayagarm block in Paschim Medinipur District of West Bengal. Four villages were randomly selected from one block and from each village, 25 respondents randomly selected, making a sample of 100 respondents. The primary data were collected with the help of the personal interview method during the study period. After collection of data, data were processed and analyzed in accordance with the outline laid down for the purpose at the time of developing the research plan. Process implies editing, coding, classification and tabulation 
of collected data. The Main statistical tools and techniques used in the present study are as follows: score, mean score value, standard deviation, correlation coefficient and paired ' $\mathrm{t}$ ' test.

\section{Results and Discussion}

Impact of the National Rural Employment Guarantee Scheme on the socio-economic condition of the beneficiary household

Here, $\bar{D}=\frac{25700}{4}=6425$

$\sum(D-\bar{D})^{2}=\sum D^{2}-\frac{\left(\sum D\right)^{2}}{N}$

$=173830000-(25700)^{2} / 4$

$=173830000-660490000 / 4$

$=173830000-165122500$

$=8707500$

S.E. of $\bar{D}=\sqrt{\frac{\sum(D-\bar{D})^{2}}{N(N-1)}}$

$\sqrt{8707500 / 12}$

$\sqrt{725625}$

$=851.83$

$t=\frac{\bar{D}}{\text { S.E. of } \bar{D}}$

$=6425 / 851.83$

$=7.54$

D.F $=3$

The computed value of paired " $\mathrm{t}$ " test with 3 degree of freedom and 5\% level of significance was 7.54 , which was greater than the table value at $5 \%$ level of significance (i.e., 3.182). This implies that the difference between the mean annual incomes of the two gram panchayat is highly significant. Therefore the null hypothesis is rejected (i.e. the mean annual income of the beneficiary household did not differ significantly after obtaining wage employment under the MGREGA) (Table 1).
Utilization of additional income from MNREGA schemes by beneficiary household

The data in table 2 indicates that 53 percent of the household beneficiaries utilized their increased income to make new houses. 32 percent beneficiary households utilized their extra income to marry their daughters off. 28 percent beneficiary households opened saving accounts in various bank. 21 percent beneficiary household repaid their cooperative loan and 35 percent household utilized their increase income to buy new furniture's mainly wooden tools, aluminum tools, iron tools etc. 19 percent beneficiary household utilized their increased income for leasing land for one year or two years. 16 percent households bought domesticated animals like hen, goat, sheep, cow and buffalo etc. 7 percent beneficiary household utilized their increase income to deposit in post office accounts. 14 percent beneficiary household bought new bicycle and 25 percent beneficiary household bought electronics gadgets.

It is clear from the above table that payment of wages is the major problems faced by the beneficiary households. Another problem as perceived by the beneficiary household is that it is not always possible for the beneficiaries to select the working place. 68 percent beneficiary households stated that the work is always not available at the near villages. 63 percent household stated that the distance of the bank from the villages is also a major cause of concern. Similarly, 55 percent of the households are ignorant about the rules of payment of wages. 51 percent beneficiary household stated that due to the lack of database of the previous works it is not possible for smooth continuation of the work under MNREGA. 50 percent of the households have perceived inadequate drinking water facilities as a problem while 42 percent of them feel that the involvement 
of shadow contractors is a problem in getting direct benefits through the job scheme, 34 percent of the beneficiary households feel that they have little information about the rights under MNREGA and 16 percent of the household fell that the works involves risks as the probability of accidents is high in some of the cases (Table 3 ).

Table.1 Calculation (Paired ' $t$ ' test)

\begin{tabular}{|c|c|c|c|c|}
\hline No & $\begin{array}{c}\text { A(Before getting } \\
\text { job) Mean }\end{array}$ & $\begin{array}{c}\text { B(After getting job) } \\
\text { Mean } n=25\end{array}$ & D=B-A & $\mathbf{D}^{\mathbf{2}}$ \\
\hline $\mathbf{1}$ & 13000 & 20900 & 7900 & 62410000 \\
\hline $\mathbf{2}$ & 15400 & 23100 & 7700 & 59290000 \\
\hline $\mathbf{3}$ & 16600 & 22400 & 5800 & 33640000 \\
\hline $\mathbf{4}$ & 14200 & 18500 & 4300 & 18490000 \\
\hline Total & $\mathbf{5 9 2 0 0}$ & $\mathbf{8 4 9 0 0}$ & $\mathbf{2 5 7 0 0}$ & $\sum \mathbf{D}^{2}=\mathbf{1 7 3 8 3 0 0 0 0}$ \\
\hline
\end{tabular}

Table.2 Way in which the beneficiary household utilized their increased income

\begin{tabular}{|l|c|c|}
\multicolumn{1}{|c|}{ Items } & Frequency & Percentage \\
\hline Construction new houses (kachha) & 53 & 53 \\
\hline Daughters marriage & 32 & 32 \\
\hline Open new Bank accounts & 28 & 28 \\
\hline Repayment of cooperative loans & 21 & 21 \\
\hline Bought furniture's & 35 & 35 \\
\hline Taken land on lease basis & 19 & 19 \\
\hline Bought domestic animals & 16 & 16 \\
\hline Open Fixed deposit accounts in post office & 7 & 7 \\
\hline Bought bicycle & 14 & 14 \\
\hline Bought electronics gadgets & 25 & 25 \\
\hline
\end{tabular}

Table.3 Problem faced by the beneficiary household in obtaining benefits of the program

\begin{tabular}{|l|c|c|}
\multicolumn{1}{|c|}{ Problem } & Frequency & Percentage \\
\hline Work is always not available near the villages & 68 & 68 \\
\hline Payment of wages is not timely. & 93 & 93 \\
\hline Less information regarding the job. & 34 & 34 \\
\hline Database of the total work done is not kept properly. & 51 & 51 \\
\hline $\begin{array}{l}\text { It is not always possible for the beneficiaries to select the } \\
\text { working place. }\end{array}$ & 78 & 78 \\
\hline Lack of drinking water facility. & 50 & 50 \\
\hline $\begin{array}{l}\text { A payment of wages through the bank is not always } \\
\text { possible as it is too far from the village. }\end{array}$ & 63 & 63 \\
\hline Job card are not issued on the work site. & 26 & 26 \\
\hline Involvement of shadow contractor. & 42 & 42 \\
\hline Ignorance regarding the rules of payment. & 55 & 55 \\
\hline Risk of accidents in the work site is probably high. & 16 & 16 \\
\hline
\end{tabular}


Table.4 Suggestion of the beneficiary household to overcome the problems in gaining the benefits of the programme

$\mathrm{N}=100$

\begin{tabular}{|l|c|c|}
\hline \multicolumn{1}{|c|}{ Suggestion } & Frequency & Percentage \\
\hline Timely payment of wages. & 64 & 64 \\
\hline Details information should be given regarding the job under this act. & 36 & 36 \\
\hline Working place in work site should not be biased. & 21 & 21 \\
\hline All facility should be provided in proper time work site. & 33 & 33 \\
\hline $\begin{array}{l}\text { The implementing agencies should keep proper track of the } \\
\text { implementation of the programme. }\end{array}$ & 18 & 18 \\
\hline
\end{tabular}

The data in table 4 indicated that 64 percent of the beneficiary household suggested for timely payment of wages. 36 percent household suggested giving detail information regarding the job in this scheme. 33 percent of the beneficiary households felt that the provision of all facilities will help them in attaining the benefits of the scheme. 21 percent beneficiary household suggested not to be biased on the choices of work site and 18 percent of the beneficiary households suggested that the implementing agencies should keep proper track record of the implementation of such programs.

It has been concluded that most of the farmers within the research locale prefer to get registered under MNREGA schemes as they get a better chance of earning extra income through such schemes to cater to their additional personal and family needs. It has also been observed that the income of farmers have considerably increased after the implementation of such schemes in the entire selected research areas. But, in spite of the better success of the schemes it also has some faults i.e., the implementing agencies often faced lack of fund in the middle of the work and so the work had to be stopped until further provision of the fund and lack of adequate and devoted administrative and technical staff for MGNREGA at official level is the main impediment for procedural lapses. So to overcome such problems it can be suggested that, dedicated and fully trained full time professional should be appointed for the effective implementation of the scheme and efforts should be made to reduce the time gap between work done and payment received by rural laborers in NREGA or a program for generating public awareness about the program with the help of information technology should be initiated at a large scale at different time intervals.

\section{Acknowledgements}

The authors hereby acknowledge the improvement brought about in this paper due to the valuable comments of editors and referee.

\section{References}

Adhikari, A. and Bhatia, K. (2010). NREGA Wage Payments: Can we bank on the Bank? Econ Pol Weekly, 55: 30-37.

Bebarta, P. K. (2013). Impact of MGNREGA in the Lives of Tribal People: A Study of Rayagada Block in Gajapati District, Odisha Review, February-March.

Drèze, J. and Christian, O. (2007). Commendable Act Frontline, 24(14): 45-48.

Muthusamy, R. (2012). The role of Mahatma Gandhi National Rural Employment Guarantee scheme in poverty alleviation in India. International Journal of Research in Commerce, Economics and Management, 2(11): 119-123. 
Poonia, J. (2012). Critical Study of MGNREGA: Impact and women's participation. International Journal of
Human Development and Management Sciences, 1: 35-55.

\section{How to cite this article:}

Deepak Hembram, A.K. Bandyopadhyay, Lokesh Kumar Tinde, Dibyendu Pal and Kshitij Parmar. 2017. Study on MGNREGA Scheme: The Securing Employment Incomes, Utilization, Problems and Suggestions. Int.J.Curr.Microbiol.App.Sci. 6(12): 2219-2224. doi: https://doi.org/10.20546/ijcmas.2017.612.255 